\title{
Relocation to Get Venture Capital: A Resource Dependence Perspective
}

\begin{abstract}
Using a resource dependence perspective, we theorize and show that non-venture-capital-backed ventures founded in U.S. states with a lower availability of venture capital (VC) are more likely to relocate to California (CA) or Massachusetts (MA) - the two VC richest states - compared to ventures founded in states with a greater availability of VC. Moreover, controlling for selfselection, ventures that relocate to CA or MA subsequently have a greater probability of attracting initial VC compared to ventures that stay in their home state. We discuss the implications for theory, future research, and practice.
\end{abstract}

"If the hill will not come to Mahomet, Mahomet will go to the hill"

[Bacon, 1625]

\section{INTRODUCTION}

The formation of relationships between high-tech ventures and formal venture capital investors (VCs) has since long been of interest in the entrepreneurial finance literature. Relationships with VCs represent one of the most critical ties of young high-tech ventures that require substantial financial resources (Hallen, 2008). Moreover, these relationships are a catalyst for those ventures to attract other resources, including skilled labor, and value-added services (Lee, Lee \& Pennings, 2001). However, the process of raising VC is fraught with difficulties.

Recent research has advanced our understanding of the resource management actions that entrepreneurs take to initiate ties with VCs more efficiently (e.g., Hallen \& Eisenhardt, 2012). However, these studies assume that entrepreneurs attempt to secure VC funding while their ventures keep operating within their current geographic location, which may be more or less munificent. Thus, ventures' geographic environment is often treated as a given or unalterable once entrepreneurs have made a location choice. This assumption is not limited to the literature on VC tie formation, but also characterizes the broader entrepreneurship literature (see, for instance, Holmes et al. (2016) and Welter (2007) for a similar observation). In this study, we challenge this 
assumption and propose that entrepreneurs can relocate their ventures' activities to the VC richest locations as an effective tactic to raise initial VC.

The lack of research on venture relocation as a potential resource management action is surprising given that multiple scholars have shown that ventures' geographic location is an important determinant of VC access. Indeed, VC is spatially clustered (Sorenson \& Stuart, 2001) and proximity to VCs eases the process of attracting VC because VCs generally exhibit a "strong local bias in their investment decisions" (Cumming \& Dai, 2010, pp. 378). To increase our understanding of venture relocation as a resource management action, we draw on resource dependence theory (RDT). In RDT, entrepreneurs strive to minimize their dependence on (prospective) resource providers that control critical resources (Pfeffer \& Salancik, 1978). They do so because dependence, which is a function of the importance of the resources to the focal venture and the extent to which the resources are controlled by relatively few organizations, is viewed as a source of vulnerability (Aldrich \& Ruef, 2006; Pfeffer \& Salancik, 1978).

Drawing on RDT, we theorize that non-VC-backed ventures that are founded in states with a lower availability of VC are more likely to relocate to CA or MA than ventures founded in states with a greater availability of $\mathrm{VC}$. We focus on venture relocations to $\mathrm{CA}$ and MA because these two states have exhibited the highest VC availability and investment activity for decades (Gompers \& Lerner, 1998; NVCA, 2010). ${ }^{1}$ We further theorize on the effectiveness of relocating ventures to CA or MA as a tactic to attract initial VC. Importantly, we do not argue that entrepreneurs relocate

\footnotetext{
${ }^{1}$ In 2009, for example, the total amount of funds committed to the U.S. VC industry equaled $\$ 16$ billion, of which more than $\$ 9$ billion (56\%) was committed to VC funds located in CA and $\$ 3.1$ billion (20\%) to funds located in MA. (NVCA, 2010). As we detail below, we also use relative VC availability measures in our paper that control for the number of high-tech ventures that operate in a state and thus control for the competition for VC. CA and MA not only score the highest in terms of the absolute amount of $\mathrm{VC}$ but also in terms of the relative amount of VC availability.
} 
their ventures exclusively because of a lack of $\mathrm{VC}$ in their home state, but rather that $\mathrm{VC}$ availability in the home state plays a non-trivial role in relocation decisions.

We use a large-scale longitudinal dataset of independent, high-tech ventures founded in the U.S. between 1995 and 2009. Our findings suggest that non-VC-backed ventures founded in states with lower VC availability are more likely to relocate to the two VC richest states, CA and MA, compared to those founded in states with greater VC availability. Controlling for self-selection, we further find that ventures that relocate to CA or MA have a greater probability of attracting initial VC compared to ventures that stay in their home state and, interestingly, also compared to ventures that were founded in CA or MA. However, we also find that ventures that relocate to CA or MA are more likely to fail than those that stay in their home state. Additional tests show the robustness of these findings.

This study makes several contributions. We add to entrepreneurial finance research that has examined the actions that non-VC-backed entrepreneurs take to form ties with VCs (e.g., Hallen \& Eisenhardt, 2012). We theorize and provide empirical evidence on the effect of relocation on the probability of attracting initial VC. More generally, we introduce relocation as an unexplored action that allows entrepreneurs to manage environmental dependence, thereby adding to RDT (Hillman, Withers \& Collins, 2009). In this respect, we elaborate on the idea introduced by Pfeffer and Salancik (1978) that organizations can "create" a more favorable environment. While up to now, RDT studies mainly focus on political actions as a tactic to create a favorable environment (e.g., lobbying or appointing politicians to the board of directors), this tactic is mainly available to larger, established organizations. For this reason, entrepreneurial ventures' environment is often treated as a given or unalterable and determines the "rules of the game" (e.g., 
Holmes et al., 2016). Yet, our study highlights that entrepreneurs can and do change their "playing field" by relocating their ventures to environments with more abundant valuable resources.

\section{BACKGROUND LITERATURE}

RDT depicts organizations as "open systems", which are not self-contained, but rely on their environment to obtain resources necessary for survival (Pfeffer \& Salancik, 1978). While access to external resources is a critical challenge for all ventures, this challenge is particularly acute for young high-tech ventures, which often lack sufficient internal resources and are confronted with an uncertain, dynamic environment (Bradley et al., 2011). The open systems nature of ventures causes interdependence, as organizations do not "entirely control all of the conditions necessary for the achievement of an action or for obtaining the outcome desired from the actions" (Pfeffer \& Salancik, 1978, pp. 40). This dependence is viewed as a source of vulnerability, which organizations seek to minimize (Aldrich \& Ruef, 2006; Dunford, 1987)

Consistent with RDT, research portrays entrepreneurs as decision makers who use a variety of actions to reduce their dependence. These actions may include (1) absorption of dependence, where ventures reduce the importance of specific resources, cultivate alternatives, or expand domains through integration, mergers or acquisitions; (2) negotiation of dependence, where ventures establish cooperative relationships, including interorganizational relationships and interlocking directorates; and (3) shaping the environment, for instance through political actions by using governmental and judicial channels leading to an environment that is better for their interests (Hillman et al., 2009).

Despite this variety of resource dependence-reducing actions, in RDT entrepreneurs are generally assumed to act within the constraints of their ventures' existing geographic environment. This assumption has also been made in much of the research on network tie formation, access to 
capital and entrepreneurial clusters. Studies on tie formation and access to VC, for instance, often depict entrepreneurs as attempting to secure VC funding while they keep operating within their current location, which may be more or less munificent (e.g., Hallen \& Eisenhardt, 2012). In the literature on entrepreneurial clusters, entrepreneurs are either located in such clusters or not and being located in a cluster brings along advantages, such as the availability of suppliers, capital providers, skilled labor, regional institutions, but also disadvantages, such as increased competition over valuable resources (e.g., Folta, Cooper, \& Baik, 2006).

The assumption that entrepreneurs act within the constraints of their ventures' existing geographic location is surprising because a venture's geographic location may be an important source of dependence in itself (Knoben \& Oerlemans, 2008). Indeed, the dependence of a focal venture on other organizations is "the product of the importance of a given input... and the extent to which it is controlled by relatively few organizations" (Pfeffer \& Salancik, 1978, pp. 51). While venture relocation will not influence the importance of a particular resource for the focal venture, it may influence the supply of the resource and the number of organizations that control the critical resource, particularly when prospective resource providers are spatially clustered. Since geographical proximity facilitates the successful exchange of external resources (Schutjens \& Stam, 2003; Knoben \& Oerlemans, 2008), seeking to be close to resources is a relevant resource dependency strategy (Galbraith, Rodrigues \& DeNoble, 2008). Hence, relocation is a possible action entrepreneurs may take to reduce their dependence on any resource provider that controls valuable resources.

In this paper, we examine the relocation of activities to new geographic locations, i.e. a tactic by which entrepreneurs change the geographic environment (including the supply of spatially constrained valuable resources such as VC) in which they operate. Our focus is 
fundamentally different from previous research that examined how existing environments evolve (e.g., Feldman, 2014) and how entrepreneurs try to influence their existing environment (e.g., Holmes et al., 2017).

Below, we develop our hypotheses in the context of young, high-tech ventures operating in distinct U.S. states characterized by a fundamentally different supply of VC. Although we recognize that states represent a relatively broad geographic classification, we focus on venture relocation across state borders for two reasons. First, VC investment levels are fundamentally different across U.S. states and are still bounded to the state level. Cumming \& Dai (2010: 378), for instance, find that "VCs invest predominantly in the new ventures that are located in their home states". Second, defining each state as a distinct geographic area provides theoretical and empirical consistency with prior VC work (e.g., Cumming \& Li, 2013; Popov, 2014). Still, we acknowledge that there exists within-state variation in the availability of VC as well. Ideally, we would also use finer-grained within-state data, but such data is not available for several variables; thus, consistent with prior research, we proxy for the unavailability of finer-grained geographic data with statelevel data. However, it is important to note that within-state variability creates "noise" in our study and thus biases our results against finding support for our hypotheses.

\section{HYPOTHESES}

\section{Supply of VC in the Home State and Venture Relocation to CA or MA}

Most entrepreneurs start their ventures in a familiar location (Dahl \& Sorenson, 2012; Michelacci \& Silva, 2007). This location often plays an important role in opportunity identification and initial venture development, including resource acquisition. However, as ventures develop, they may require access to new resources that are not abundant in their existing geographic location, particularly when they have high growth ambitions and are active in high-tech industries. VC is 
one such resource because these ventures often do not generate (sufficient) internal funds to finance their growth ambitions (Carpenter \& Petersen, 2002a). Moreover, other sources of external finance are unsuitable (in the case of debt finance, see Carpenter \& Petersen, 2002b) or are characterized by smaller average investment amounts (in the case of debt finance, see Vanacker \& Manigart, 2010; or angel money, see Hellmann, Schure \& Vo, 2015). Thus, high-tech ventures with high growth ambitions may either directly approach VC (Hellmann et al., 2015) or may need to raise VC later-on (Berger \& Udell, 1998).

However, VC is characterized by strong spatial clustering (Cumming \& Dai, 2010; Sorenson \& Stuart, 2001). In the U.S., CA and MA have by far been the two leading states in terms of VC fund availability for several decades (Gompers \& Lerner, 1998). ${ }^{2}$ The uneven spatial distribution of $\mathrm{VC}$ is problematic for ventures founded in states characterized by a relative paucity of VC because they have lower probabilities of attracting initial VC (Stuart \& Sorenson, 2003). Attracting money from distant regions turns out to be a difficult strategy because VCs prefer geographic proximity to their targets. This proximity facilitates venture identification, evaluation and post-investment monitoring (Mäkelä \& Maula, 2006; Sapienza, Manigart \& Vermeir, 1996; Sorenson \& Stuart, 2001). Despite progress in telecommunication technologies, local presence and face-to-face contact are still favored (Fritsch \& Schilder, 2008; Gupta \& Sapienza, 1992) and VCs require significantly higher rates of return for long-distance investments (Chen et al., 2010).

VCs themselves may seek to mitigate liabilities related to distance by syndicating with local VCs that can act as leads in these deals (e.g., Devigne et al., 2013; Sorensen \& Stuart, 2001).

\footnotetext{
${ }^{2} \mathrm{CA}$ and MA are quite diverse in terms of their technological focus and the nature of their VC system, though. While CA is highly renowned for its ICT business and VC investors frequently originate from the industry itself, MA is characterized by a set of "technology mini-clusters" in a larger number of high-tech industries and a VC industry that is dominated by the financial sector (Best, 2015; Hulsinck, Manuel \& Bouwman, 2007). However, key for our study is that despite their differences both states are by far the VC richest states.
} 
However, in states with a lack of VCs, this initial enabler is almost by definition inaccessible. Consequently, most long-distance VC investments also flow to VC rich regions (Fritsch \& Schilder, 2008), explaining why long-distance investing tends to reinforce the geographic concentration of VC investing. Hence, non-VC-backed ventures founded in states where $\mathrm{VC}$ is scarce will depend on a limited set of prospective VCs and will face significant difficulties in accessing initial VC from both local and distant VCs. ${ }^{3}$

In the spirit of RDT, prior research has shown how entrepreneurs may absorb their dependence on VCs. For example, entrepreneurs can resort to financial bootstrapping - techniques used to reduce the need for external financing (Ebben \& Johnson, 2006). Moreover, entrepreneurs may cultivate alternatives to VC (Hallen \& Eisenhardt, 2012). For example, ventures may seek to attract angel money. ${ }^{4}$ However, financial bootstrapping and alternative external financing sources, such as angel money, may not be a perfect substitute for VC since they may not provide all of the resources necessary for ventures with high growth ambitions (e.g., Hellmann et al., 2015; Sapienza, Korsgaard \& Forbes, 2003). Indeed, bootstrap finance and angel money tend to cover smaller financing needs, but are unlikely to cover all financing needs as ventures grow (Berger \& Udell, 1998). Thus, while entrepreneurs may initially delay (or avoid) raising VC to finance their

\footnotetext{
${ }^{3}$ We acknowledge that in boom periods, where VCs heavily compete for deal flow (particularly in the VC richest states), VCs could become dependent on ventures as well. Thus, it is possible that resource dependence works the other way around and pushes VCs to invest over longer distances to get access to good deal flow. However, even during country-wide boom periods, VC remains relatively scarce in VC poor states. Thus, ventures in VC poor states will still be dependent on a limited set of prospective VCs because even during boom periods geographic distance matters (to some extent). Indeed, Cumming and Dai (2013) provide evidence that in general the geographic distance between VCs and new ventures has become shorter over the 30-year period of their study and the 1998-2000 bubble period, for instance, did not cause a shift in this general trend.

${ }^{4}$ While there are indications that angel money is also spatially clustered (Stangler, Tareque \& Morelix, 2016), it is more homogeneously spread across the U.S. than VC. However, while progress has been made with respect to the collection of angel data at a national level, high-quality data on investments at the state level is still lacking (Kauffman Foundation, 2016). In the robustness section, we control for the availability of angel money at the state level and our results remain qualitatively similar. Another source of finance that recently gained attention is crowdfunding, but as highlighted by Mollick \& Robb (2016, pp. 79) "crowdfunding relaxes geographic constraints, but not completely". However, this funding source was still in its infancy during the period of our study.
} 
early growth, high-tech ventures with high growth ambitions will eventually need to consider searching for $\mathrm{VC}$ or, alternatively, they may have to tune down their growth ambitions.

Whereas scholars have focused on tactics that non-VC-backed ventures deploy within their current geographic location to reduce dependence on VCs, entrepreneurs should not take their VC poor location as given. ${ }^{5}$ The dependence of a focal venture on VCs is a joint function of the importance of $\mathrm{VC}$ for the focal venture and the extent to which $\mathrm{VC}$ funds are controlled by relatively few VCs. Pfeffer and Salancik (1978, pp. 51), for example, argue that "a resource that is not important cannot create a situation of dependence", and importantly "regardless of how important the resource is, unless it is controlled by relatively few organizations, the focal organization will not be particularly dependent on any of them". Thus, entrepreneurs can relocate their ventures' activities to states with a greater availability of VC funds as a tactic to reduce their dependence on a limited set of prospective VCs in their home state.

However, RDT also suggests that one tactic will rarely solve all dependence issues and, in fact, often creates new dependencies (Pfeffer, 1987). Relocation to a VC richer state may, for instance, introduce new dependencies because it radically shifts existing relationships with customers, suppliers, and employees (Brouwer, Mariotti \& Van Ommeren, 2004; Isabella, 1990). In addition to losing ties with existing resource providers, relocating also implies an important social cost for entrepreneurs and their family (Dahl \& Sorenson, 2012; Kulchina, 2016). For this reason, entrepreneurs will only be willing to relocate if the perceived benefits of relocation outweigh the costs. Hence, if entrepreneurs want to minimize their dependence on prospective VCs by relocating their ventures, they are especially likely to relocate ventures founded in states

\footnotetext{
${ }^{5} \mathrm{We}$ focus on the relocation decision of ventures that have not yet raised VC. We do so to exclude the possibility that VCs push their portfolio companies to relocate, for instance, to facilitate monitoring (e.g., Cumming, Fleming \& Schwienbacher, 2009).
} 
with a limited availability of $\mathrm{VC}$ funds to the $\mathrm{VC}$ richest states. The perceived benefits of relocating to the $\mathrm{VC}$ richest states may not outweigh the costs for ventures founded in states with a greater availability of $\mathrm{VC}$ funds. Thus,

Hypothesis 1: Non-VC-backed high-tech ventures founded in states with a lower availability of VC funds are more likely to relocate to CA or MA, compared to ventures founded in states with a greater availability of VC funds.

\section{Relocation to CA or MA and the Ability to Attract Initial VC Finance}

If entrepreneurs turn out to relocate their non-VC-backed high-tech ventures to the $\mathrm{VC}$ richest states to diminish their dependence on a limited set of prospective VCs in their home state, a key question that emerges is: do relocated ventures have a higher probability of raising $\mathrm{VC}$ after relocation? We focus on attracting initial $\mathrm{VC}$ for the venture because raising follow-on $\mathrm{VC}$ funding may be the consequence of either having relocated or having raised initial VC (e.g., the network of initial VCs is likely to influence follow-on VC funding). Focusing on first rounds only hence allows for a cleaner examination of the impact of relocation on the probability of raising VC.

To address the above question, we compare non-VC-backed ventures that relocated to CA or MA with (a) those founded outside CA or MA that did not relocate and (b) those founded in CA or MA. This dual comparison is important because ventures that relocate to CA or MA may restructure their resource dependencies in two distinctive ways. First, the availability of locationbounded resources may increase substantially for relocated ventures compared to ventures staying outside CA or MA (Knoben, 2011). Second, the accessibility of location-bounded resources may be more problematic for relocated ventures that lack the local embeddedness of ventures founded 
in CA or MA (Knoben, Oerlemans \& Rutten, 2008). Overall, making both comparisons enables us to provide finer-grained insights on the effects of relocation to manage resource dependencies. ${ }^{6}$

Attracting initial VC is a key challenge. VCs face significant time constraints and the majority of investment proposals they receive do not get more than a few minutes of their attention during a quick screening (Fried \& Hisrich, 1994). When entrepreneurs relocate their ventures to CA or MA, they alleviate the central issue of distance (Cumming \& Dai, 2010) as they get close to a large pool of spatially clustered VC funds compared to entrepreneurs that remain in their VC poor home state. The VC literature provides ample evidence of VCs that do not consider a significant part of their deal flow after a quick screening based on general criteria such as the distance between the venture and VC (e.g., Cumming \& Dai, 2010; Fried \& Hisrich, 1994; Gupta \& Sapienza, 1992). They do so because reduced distance between portfolio companies and VCs facilitates selection and value-adding activities (e.g., Gupta \& Sapienza, 1992). Thus, only by relocating their ventures to $\mathrm{CA}$ or MA, entrepreneurs may already be better able to capture the limited attention of a larger set of VCs, and increase their odds of surviving the quick screening, compared to entrepreneurs that remain in less $\mathrm{VC}$ rich states. ${ }^{7}$

Furthermore, relocating to CA or MA may increase the desirability of ventures in the selection process relative to ventures that remain in a less $\mathrm{VC}$ rich home state. First, ventures that relocated to CA or MA are close to a larger set of prospective VCs, thereby enhancing their chances to informally meet with these VCs. Relocated entrepreneurs may hence "develop a network of

\footnotetext{
${ }^{6}$ We can never observe the case of what would have happened to relocated ventures if they had not relocated. As we detail later, we empirically control for such self-selection issues (Heckman, 1979). Thus, we account for the fact that relocated ventures might differ from non-relocated ones in terms of unobservable characteristics (e.g., relocated ventures might have had a larger probability of attracting VC because of some unobservable characteristics).

${ }^{7}$ Nevertheless, relocated ventures may also face increased competition from a higher number of VC-seeking firms (e.g. Folta et al., 2006; Stuart \& Sorenson, 2003). Empirically, we will tackle this issue by using relative VC availability measures that correct for the number of high-tech ventures active in a state (and hence incorporate issues related to competition for $\mathrm{VC}$ funds).
} 
potential partners who are familiar with and have positive affect for a venture prior to its seeking a formal tie" (Hallen \& Eisenhardt, 2012, pp. 45). Indeed, when prospective VCs' informal advice is followed, this may not only improve (perceived) venture quality but also "co-opt" VCs by engaging them in the venture's development (Hallen \& Eisenhardt, 2012). Second, the VC richness of CA and MA often coincides with the increased presence of other location-bounded resource providers such as highly skilled employees, consultants, business accelerators and councilors (Folta et al., 2006). These resource providers not only enhance opportunities for further venture development - thereby increasing the attractiveness of the relocated venture-but they also increase a venture's ability to encounter and interact with VCs (Amezcua et al., 2013; Sorenson \& Stuart, 2001).

Overall, ventures that relocated to CA or MA should not only be able to attract the attention of a larger set of VCs compared to ventures that remain in a less VC rich home state, relocation will also increase their attractiveness for a larger set of prospective VCs. The dependence of relocated ventures on any single VC will hereby decrease. As Pfeffer \& Salancik (1978, pp. 52) note "when there are many sources of supply...the power of any single one [resource provider] is correspondingly reduced". Consequently, the relocation to CA or MA provides ventures founded outside CA or MA with more opportunities, power, and leverage to form ties with a larger set of prospective VCs compared to entrepreneurs of ventures that stay in their home state. Thus,

Hypothesis 2a: For non-VC-backed, high-tech ventures that are founded outside CA or $M A$, ventures that relocate to CA or MA have a higher likelihood of raising initial VC than those that stay in their home state.

Location-bounded resources, including VC, are equally available for ventures that relocated to CA or MA and for ventures that were founded in CA or MA (i.e., "home-grown" 
ventures), given that they share the same geographic location. However, equal resource availability does not imply equal resource accessibility. We hypothesize that relocated ventures will be at a disadvantage compared to ventures founded in CA and MA to secure initial VC due to their more limited embeddedness in their new location. ${ }^{8}$

One key concern that VCs have during the screening and selection of investment proposals is information asymmetry - the situation where entrepreneurs possess information about themselves and their opportunities that VCs do not possess (Amit, Brander \& Zott, 1998). Preexisting direct and indirect connections between entrepreneurs and prospective VCs provide an important mechanism through which information asymmetry problems are overcome in VC investing (Shane \& Cable, 2002). Pre-existing connections, for instance, provide a fast way to obtain private information about the quality of specific entrepreneurs. Consistent with these ideas, Shane \& Cable (2002) show that both direct and indirect connections between entrepreneurs and VCs positively influence the probability of attracting initial VC. Ventures that relocated to CA or MA are likely to be at a disadvantage — at least for the first couple of years after relocating relative to home-grown ventures in terms of their local embeddedness.

When ventures reside in the same geographic location for longer, they create close connections with local suppliers, customers and other stakeholders (Brouwer et al., 2004). Thus, it will take time and effort for relocated ventures to develop new connections in CA or MA after relocating. Further, information from local business connections can enable entrepreneurs to scrutinize the interest of VCs in the state, thereby allowing them to approach VCs more efficiently (Plummer, Allison \& Connelly, 2016). Because of their more limited local connections, entrepreneurs from relocated ventures may have less access to such information relative to

\footnotetext{
${ }^{8}$ Rather than relocating their ventures' activities, entrepreneurs may decide to set up a branch in CA or MA, and remain active in their home state at the same time. We come back to this possibility in the robustness section.
} 
entrepreneurs of home-grown ventures. Moreover, the more limited local connections of relocated ventures may hamper the ability of VCs to evaluate the quality of ventures and to obtain information on their prior activities (Gupta \& Sapienza, 1992), leading to higher levels of information asymmetry compared to home-grown ventures. The problem of informational asymmetry is particularly severe when making initial investment decisions because venture information is uncertain and difficult to verify, the venture's strategic direction may still shift significantly and there is no track record with respect to what ventures are able to accomplish with the money they might receive (e.g., Plummer et al., 2016; Gompers, 1995). Because of their more limited local embeddedness, these problems represent hurdles that will be more difficult to overcome for relocated ventures relative to home-grown ventures. ${ }^{9}$ Thus,

Hypothesis 2b: For non-VC-backed, high-tech ventures that are located in CA or MA, ventures founded outside CA or MA have a lower likelihood of raising initial VC than those founded in CA or MA.

\section{METHODS}

\section{Data Sources and Sample}

We rely on the National Establishment Time-Series (NETS) Database, which provides annual geographic, descriptive and performance data on over 44 million U.S. business establishments. This data includes industry codes, sales levels, employment levels, ownership type, credit score, and location. Several recent studies (e.g., Amezcua, et al., 2013; Levine \& Toffel, 2010; Neumark, Wall \& Zhang, 2011; Paglia \& Harjoto, 2014) have validated the NETS database. Information on

\footnotetext{
${ }^{9}$ Entrepreneurs can try to limit these problems by relocating relatively quickly after founding. However, our data suggests that less than $30 \%$ of the firms that relocate to CA or MA do so within the first three years of existence. In addition, about half of the ventures in our dataset move to CA or MA between the 4th and the 7th year of existence. Thus, quick relocations after founding are uncommon, which may not be surprising given that relocations entail direct and indirect costs for ventures as well as important social costs for entrepreneurs.
} 
VC investments is obtained through Pitchbook, which contains annual information on ventures that receive VC. State-level data are gathered from the National Venture Capital Association, the Federal Deposit Insurance Corporation, the National Bureau of Economic Research, the National Science Foundation and the U.S. Patent and Trademark Office.

We focus on ventures that were founded as independent entities in the period 1995 to 2009 within the high-tech industry. Following Hecker (2005), we classify a venture as high-tech if it operates in an industry with a technology-oriented employment rate exceeding five times the average of other industries. The selection criteria result in a longitudinal unbalanced panel dataset with $1,102,710$ venture-year observations of 155,435 high-tech ventures. Ventures are tracked from founding until 2009. Ventures that cease to report Dun \& Bradstreet (D\&B) data before 2009 (e.g., because of failure) are included in our sample until their final year of existence, which minimizes issues of survival bias. Our sample therefore covers a wide range of development stages with venture age ranging from 0 to 16 years old and sales levels ranging from $\$ 124,000$ to $\$ 11,600,000$.

\section{[Insert Table 1 Here]}

Table 1 provides an overview of the distribution of our sample ventures (Panel A), our relocations (Panels B and C) and VC finance (Panel D) across U.S. states. ${ }^{10}$

To test our hypotheses, we use additional sample selection criteria. To test Hypothesis 1 , we focus on first-time relocations of ventures that did not yet obtain VC. Consistent with our econometric approach, which we describe below, ventures drop out of our sample after relocation to CA or MA (or any other U.S. state) or after having raised VC for the first time. Ventures that

\footnotetext{
${ }^{10}$ Ventures founded in Puerto Rico (741 ventures) and the Virgin Islands (25 ventures) are not included in our main analyses due to the limited availability of independent and control variables.
} 
relocate and receive $\mathrm{VC}$ in the same year are also excluded from the sample to avoid problems of reverse causality. ${ }^{11}$

To test Hypotheses $2 \mathrm{a}$ and $2 \mathrm{~b}$, we track ventures from start-up until the year they receive initial VC. Note that as all ventures in our sample are founded in the 1995-2009 period and Pitchbook covers this entire period, we capture the first VC round for the venture. Ventures that relocate and receive initial VC in the same year are again excluded from the sample. First, we compare ventures that stay in their home state to those that moved to CA or MA. Ventures founded in CA or MA as well as ventures relocating to other states are excluded as of the year of relocation. Second, we compare ventures that were founded in CA or MA to those that moved to CA or MA. Those that move are incorporated in our sample as of the year after relocation. Consistent with our theory development, we only consider relocations to CA or MA from states where VC is less abundant. Relocations between CA and MA are therefore excluded.

\section{Dependent Variables}

To test Hypothesis 1, the dependent variable is Relocation to CA or MA. This variable is a dummy variable, equaling one if a non-VC-backed venture moves to CA or MA and zero otherwise. Panel B of Table 1 reports that 4,906 non-VC-backed ventures relocate. As highlighted in Panel C of Table 1, $671(14 \%)$ move to CA or MA. Although this is a rare event, CA and MA attract a disproportionate number of relocating ventures. The states with the highest proportion of ventures relocating to CA or MA are New Hampshire (3\%), Nevada (3\%), Rhode Island (2\%), Connecticut $(1 \%)$ and Utah $(1 \%)$.

\footnotetext{
${ }^{11}$ As we explained before, we do so because VCs might also push their ventures to relocate (Cumming, et al., 2009). Five ventures received VC in the year they relocated. As a robustness check, we included these five ventures. The results remain unchanged.
} 
To test Hypotheses 2a and 2b, the dependent variable is Venture capital. This variable is a dummy variable, equaling one if the venture attracted initial VC in a given year and zero otherwise. Our sample consists of 2,394 ventures (1.54\%) that attracted initial VC between 1995 and 2009 (Table 1, Panel D). Panel D confirms that VC is spatially clustered: of the 2,394 ventures that raise VC, $805(33.6 \%)$ are located in CA and $233(9.7 \%)$ in MA, confirming the relevance of our focus on relocation to these states.

\section{Independent Variables}

Table 2 presents the descriptive statistics of the independent and control variables. To minimize concerns of reverse causality, these variables are lagged by one year. We use inflation-adjusted measures and winsorize all continuous variables at the $5 \%$ level.

\section{[Insert Table 2 Here]}

To test Hypothesis 1, we first measure VC funds in the state of origin (absolute) as the natural logarithm of the amount of VC commitments in a given state in a given year (measured in million U.S. dollars (USD)). Table 2 shows that the average (median) level of VC funds in the state of origin equals 1.9 billion USD ( 0.2 billion USD). We also measure $V C$ funds in the state of origin (relative) as the amount of $\mathrm{VC}$ commitments divided by the total number of active hightech ventures in a given state in a given year (measured in million USD). As such, the relative measure of VC fund availability indicates how much every high-tech venture may hypothetically raise if VC funds were spread equally across all active high-tech ventures (and thus controls for issues related to competition for $\mathrm{VC}$ funds). The average (median) level of $\mathrm{VC}$ funds in the state per high-tech venture equals 90,000 USD (20,000 USD). The large difference between average and median values again highlights the huge variance in VC fund availability across states and years. 
To test Hypotheses $2 \mathrm{a}$ and $2 \mathrm{~b}$, we rely on the variable Relocation to $C A$ or $M A$ as the independent variable. This is a dummy variable, equaling one for ventures that have relocated their activities to CA or MA before raising any VC.

\section{Control Variables}

The relocation models to test Hypothesis 1 control for several venture characteristics from the NETS database. Venture size is measured as the natural logarithm of sales in a given year. Venture age is measured as the natural logarithm of the number of years since incorporation. We include these two controls because smaller and younger ventures are less regionally embedded (Knoben, 2011). We also include Credit report availability, which indicates whether the venture has a D\&B PayDex score in a given year. This score is based on trade experiences reported to D\&B by various vendors. Credit-reporting ventures reduce information asymmetry for resource suppliers both in familiar and unfamiliar locations. Venture size, venture age and information asymmetry also capture the dynamics proposed in standard models on the evolution of entrepreneurial finance (Berger \& Udell, 1998). Thus, these variables control for the possibility that relocation to a VC cluster may be a natural transition in entrepreneurial development. In addition, we control for venture growth and human resource (HR) slack. Venture growth is measured as the relative increase in sales and proxies for resource needs. HR slack is measured as the number of employees relative to sales, from which the median ratio of employment to sales in the industry (at the 4-level NAICS digit score) is subtracted (Bradley et al., 2011). Ventures may build up higher levels of HR slack to prepare for future growth and may hence require more financial resources (e.g., Welbourne, Neck \& Meyer, 1999).

Other ecosystem advantages, such as a high-quality infrastructure in the home state may decrease the probability of relocating (Weterings \& Knoben, 2013). Specifically, next to funding, 
access to ventures operating in the same industry, innovation activities and human capital are important spatial resources (Feldman, 2014; Isenberg and Onyemah, 2016). We therefore include several proxies for the entrepreneurial infrastructure at the state level in any given year. Industry density is measured as the number of ventures active in the same industry (at the 3-level NAICS digit score) as the focal venture in a given state in a given year. This variable controls for the specialization of labor, suppliers and other input factors in the venture's state (Weterings \& Knoben, 2013). Patents per thousand inhabitants is defined as the number of granted patents per thousand inhabitants in a given state in a given year. This variable proxies for knowledge spillovers and innovation activity at the state level (Bradley et al., 2011). GDP per capita is defined as real GDP per capita for a given state in a given year and controls for the current prosperity of the state. The presence of a high-quality workforce is measured by the level of educational attainment, operationalized as the number of Science and engineering graduate students between 25 and 34 years old per 1,000 individuals. Local banking development is measured as the total amount of loans and leases provided by financial institutions per high-tech venture. Local banking development is associated with increased financial resource access and better loan conditions for entrepreneurs (Deloof \& La Rocca, 2015). Finally, the Long term capital gains tax rate is defined as the marginal state tax rate on long capital gains and is measured through the use of the NBER TAXSIM tax simulation program. A higher capital gains tax rate is expected to be negatively related to the attractiveness of the home state (Gompers \& Lerner, 1998).

In addition to the state level variables that proxy for the entrepreneurial infrastructure, we also control for the proximity to CA or MA by incorporating the dummy variable Neighbor. This variable equals one if the venture is founded in a neighboring state of CA or MA. It controls for the familiarity with CA or MA and for the lower cost of relocation for ventures that originate from 
neighboring states (Brouwer et al., 2004). We expect ventures founded in neighboring states to have a higher probability of relocation to CA or MA. Finally, all regression models capture industry and time effects through the incorporation of industry and year dummies.

The models that investigate the attraction of initial VC to test Hypotheses $2 \mathrm{a}$ and $2 \mathrm{~b}$ control for venture characteristics that are associated with the investment criteria used by VCs (e.g., Fried \& Hisrich, 1994) and thus with the likelihood of obtaining initial VC. We need to control for these characteristics to be able to disentangle the effects of "typical" VC selection criteria from the effects of relocation. Specifically, since VCs target ventures with high growth potential, we include Venture growth and HR slack. Venture size and Credit report availability proxy for the level of information asymmetries between high-tech ventures and VCs (Sapienza et al., 2003; Vanacker, Collewaert \& Paeleman, 2013). Lower levels of information asymmetries are expected to increase the probability of raising VC (Amit et al., 1998). The operationalization of these variables is described above. We further include state fixed effects. These effects control for all, even unmeasured, stable differences between states.

Table 2 shows that the average venture in our dataset is five years old and has $\$ 2.2$ million sales (median: $\$ 1.1$ million). $44 \%$ of all ventures have credit reports. The average venture has an annual sales growth of $14 \%$ (median: $0 \%$ ) and HR slack level of .54 . With respect to state level characteristics, Table 2 indicates an average industry density of 3,682: there are, on average, 3,682 ventures active in the same (3-digit high-tech) industry and state in a given year. The number of patents averages .30 per thousand inhabitants. States have on average 11.59 science and engineering graduate students per 1,000 individuals. Some $11 \%$ of the ventures originate from a state adjacent to CA or MA.

\section{Method of Analysis}


To test hypothesis 1 , we use a Cox proportional hazard model, which predicts the hazard of relocation to CA or MA for each of the venture-years. All independent and control variables are time-varying. Our Cox proportional hazard models are of the form:

$$
h(t)=h_{0}(t) \exp [B X]
$$

where $\mathrm{h}(\mathrm{t})$ is the hazard rate at time $\mathrm{t}, \mathrm{h}_{0}(\mathrm{t})$ is the baseline hazard function, $\mathrm{X}$ is the vector of predictors, and B is the vector of estimated coefficients.

The Cox proportional hazard model estimates an unspecified hazard rate as a function of time. In our sample, time corresponds with the age since start-up. As a result, venture age is incorporated in our models although not as a separate control. The effects of the independent variables are estimated as multipliers of the hazard rate. An advantage of the Cox proportional hazard model is that it does not require any parametric assumptions for the hazard function, which is suitable for our data as relocation is a rare event. Further, Cox proportional hazard models account for the non-independent nature of our panel data (Allison, 1995).

Cox proportional hazard models are also used to analyze the probability of raising VC (Hypotheses 2a and 2b). In this case, we predict the hazard of receiving initial VC for each ventureyear.

First, we model the hazard of receiving initial VC for the subsample of ventures founded outside CA or MA. We compare the hazard of receiving initial VC of ventures that relocate to CA or MA with that of ventures that stay in their home region. Given that relocation to CA or MA may not be randomly distributed, we correct for self-selection. While there are several approaches to deal with selection issues, we use the Heckman approach (Heckman, 1979; Li \& Prabhala, 2007). ${ }^{12}$ We thus start with a probit selection equation, modeling the likelihood of venture

\footnotetext{
${ }^{12}$ An alternative approach is to compare ventures that did not relocate to a propensity score matched sample (where this matching occurs based on observable variables) of ventures that did relocate. However, this would entail that we
} 
relocation to $\mathrm{CA}$ or MA. ${ }^{13}$ Thereafter, the inverse Mills ratio of the selection equation is incorporated as a control for self-selection in our hazard models of interest. The goal of the inverse Mills ratio is to capture the effect of unobservable factors that distinguish relocated ventures from those that stay in their state of origin.

Second, we estimate the hazard of receiving initial VC for a subsample of ventures located in CA or MA, distinguishing between ventures that relocated towards CA or MA and ventures founded in CA or MA. Again, we include an Inverse Mills selection ratio. The goal of our selection model in this analysis is to capture unobservable factors that distinguish relocated ventures from those that were initially founded in CA or MA.

\title{
FINDINGS
}

\section{The Supply of VC in the Home State and Venture Relocation to CA or MA}

Table 3 presents the results of the relocation models. A hazard ratio above one indicates a positive effect of the independent variable on the hazard of relocation to CA or MA (less than one indicates a negative effect). Model 1 includes the control variables only. Models 2 and 3 include the absolute and the relative level of VC fund availability in the home state separately (to avoid multicollinearity). When VC fund availability is added, the $\mathrm{Chi}^{2}$ likelihood ratios of the hazard models improve significantly, suggesting that VC availability is a non-trivial predictor of relocation to $\mathrm{CA}$ or MA.

\author{
[Insert Table 3 Here]
}

\footnotetext{
have a fundamentally different sample for the first part of our paper (where we want to obtain insight on whether a lack of VC funds in a venture's state of origin pushes ventures to relocate) relative to the second part of our paper (where we examine if relocation increases the odds of attracting initial VC). Instead, we prefer to leverage our largescale dataset and control for observable differences between relocated and non-relocated ventures through our set of control variables. Moreover, the Inverse Mills ratios in our approach also capture possible unobservable differences between relocated and non-relocated ventures.

${ }^{13}$ For briefness, we do not report the detailed selection models but they are available upon request.
} 
Hypothesis 1 predicts that ventures founded in states with lower VC availability are more likely to relocate to CA or MA compared to ventures founded in states with greater VC availability. Models 2 and 3 provide strong support for hypothesis 1, both when measuring VC fund availability in absolute $(\mathrm{p}<.05)$ and in relative $(\mathrm{p}<.01)$ terms. A decrease in the level of $\mathrm{VC}$ fund availability with one standard deviation increases the hazard of relocation to CA or MA with $10 \%$ in both models.

The coefficients of the control variables in Table 3 suggest that relocation to CA or MA results from a combination of venture and state characteristics. With respect to venture characteristics, the availability of a credit reporting score is positively related to the hazard of relocation. Moreover, ventures originating from states with a better entrepreneurial infrastructure, as proxied by industry density and long term capital gains tax rate, are less likely to relocate to CA or MA. Interestingly, real GDP per capita and local banking development in a state both positively affect the likelihood to relocate. Finally, ventures that relocate to CA or MA are more likely to originate from neighboring states. Combined, these findings suggest that entrepreneurs do not relocate their ventures exclusively because of a lack of $\mathrm{VC}$ in their home state as other ecosystem advantages (in addition to venture funding) also have an impact. For example, a decrease in industry density with one standard deviation increases the likelihood to relocate to CA or MA with either $2.9 \%$ (in model 2) or 20.0\% (in model 3). However, our findings show that VC availability in the home state does play a non-trivial role in relocation decisions.

\section{Relocation to CA or MA and the Ability to Attract Initial VC Finance}

Table 4 presents the models estimating the hazard of raising initial VC. The models in Panel A compare relocated ventures with those that stay in their home state (excluding ventures founded in CA or MA). The models in Panel B only include ventures located in CA or MA; they compare 
the hazard rate of raising initial VC for relocated versus home-grown ventures. Within each Panel, model 1 includes the controls only and the relocation dummy is added in model 2.

\section{[Insert Table 4 Here]}

Hypothesis 2 a proposes that ventures that relocate to CA or MA are more likely to raise initial VC compared to those that remain in less VC rich states. Our results provide strong support for hypothesis $2 \mathrm{a}$ : ventures that move to $\mathrm{CA}$ or MA are, ceteris paribus, 3.7 times more likely to raise $\mathrm{VC}$ than those that remain in their $\mathrm{VC}$ poor home state $(\mathrm{p}<.01)$. More specifically, while only $0.93 \%$ of the non-relocated ventures in this subsample raised $\mathrm{VC}, 3.42 \%$ of the ventures relocated to CA or MA did so. More than $80 \%$ of the ventures that attract initial VC after relocation to CA or MA do so within the first three years after relocation, while the remaining do so between four and six years after relocation. Hence, in line with our arguments on the benefits of relocation as a tactic to reduce resource dependencies, ventures moving to CA or MA are indeed better able to form initial ties with VCs than those staying in their home state.

Hypothesis $2 \mathrm{~b}$ is not supported, however. While we argued that relocated ventures would be less likely to attract initial VC than ventures founded in CA or MA, our findings show the opposite. More specifically, the hazard of raising initial VC is 2.1 times higher for ventures relocating to $\mathrm{CA}$ or MA, compared to home-grown ventures. Relocated ventures are thus more likely to attract initial VC despite their lower local embeddedness. ${ }^{14}$

The control variables, which represent the "typical" selection variables of VCs, have the expected signs. Specifically, lower levels of information asymmetry, proxied by venture size and

\footnotetext{
${ }^{14}$ While we highlighted before that we focus on ventures' initial VC fundraising, it is interesting to provide some additional descriptive statistics on follow-on VC funding. Slightly more than half (53\%) of non-relocating ventures that attracted initial VC attract follow-on VC rounds. For ventures that relocated to CA and MA and attracted initial $\mathrm{VC}$ this percentage is higher at $60 \%$. Thus, ventures that relocate to CA or MA seem to have additional longer-term benefits besides being more likely to raise initial VC.
} 
credit report availability increase the hazard of receiving initial VC. Not surprisingly, VCs also focus on ventures with substantial growth perspectives: HR slack and-for the subsample of ventures located in $\mathrm{CA}$ or $\mathrm{MA}$ - venture growth have a positive impact on the hazard of raising initial VC. Finally, it is worthwhile to examine the Inverse Mills ratios that account for the selfselection effects of relocation. In the subsample of ventures founded outside CA or MA, the significant Inverse Mills ratio suggests that unobservable factors that distinguish relocated ventures from those that stay in their VC poor state are (negatively) correlated with attracting initial VC. In the subsample of ventures located in CA or MA, the Inverse Mills ratio is not significant, indicating that unobservable factors that distinguish relocated ventures from those that were initially founded in CA or MA do not significantly influence the attraction of initial VC. Taken together, our results suggest that even when controlling for "typical" VC selection criteria and potential self-selection effects, relocation is an important determinant of a venture's ability to attract initial VC.

\section{Post-hoc Analyses}

So far, our results emphasize the positive effects of relocation to CA or MA. However, RDT also suggests that tactics to alleviate resource dependencies will result in novel patterns of dependence. As such, a venture will never fully eliminate resource dependencies (Pfeffer, 1987). For example, relocation may conflict with the interests of resource providers located in the home state of the entrepreneur, such as employees and local business relations (Brouwer et al., 2004). Some of these resource providers will not follow the venture to its new location and the replacement of these providers in the new location is not guaranteed (Isabella, 1990). We therefore examine whether relocated ventures are more prone to failure. 
We first model failure rates for ventures founded outside CA or MA, comparing failure rates of ventures that relocated to those that stayed in their home state. Second, we model failure rates of ventures located in $\mathrm{CA}$ or MA, comparing relocated ventures to home-grown ventures. Both models include Inverse Mills ratios to control for unobservable characteristics that distinguish relocated from non-relocated ventures.

The dependent variables in these analyses, Failure, is measured as a dummy variable that equals one if the venture is reported by $\mathrm{D} \& \mathrm{~B}$ to be out of business in a given year. The average failure rate amounts to $3.36 \%$, representing 5,228 ventures. Ventures located in CA and MA have the highest probability of failing ( $4.23 \%$ and $4.27 \%$ respectively). This finding is consistent with prior research, which suggests that despite the benefits of being located in these states, ventures also suffer from more severe competition between high-tech ventures (Stuart \& Sorenson, 2003). Most ventures tend to fail quite quickly after relocating to CA or MA: $32 \%$ of the ventures fail within the first year after relocation, another $21 \%$ fail in the second year after relocation, another $33 \%$ in the third and fourth year. Only $16 \%$ fail five years or later after relocation.

Panel A of Table 5 shows that ventures relocating to CA or MA are 1.7 times more likely to fail than those staying in their home state. Interestingly, our hazard models suggest that VCbacked ventures have lower failure rates than non-VC-backed ventures. Whereas the former group (regardless of having relocated or not) has an average failure rate of $1 \%$, the latter group has an average failure rate of $4 \%$. This finding is in line with Puri \& Zarutskie (2012), who attribute the lower failure rate of VC-backed ventures (particularly in the first years after VC funding) to their increased cash buffers following VC investments. Finally, based on Table 5, Panel B we fail to find a difference in failure rates among relocated ventures and home-grown ventures in CA or MA. 
This suggests that a lower level of embeddedness in the new location does not increase the probability of failure relative to home-grown ventures.

As a robustness check, we recoded failure based on all ventures that ceased to be registered as active companies in the database, irrespective of the reason why they ceased to exist (Tsvetkova, Thill \& Strumsky, 2014). More than $38.02 \%$ of the sample ceases to exist before the end of our sample period, which is highly similar to the failure rate reported in Tsvetkova et al. (2014). Results using this alternative measure of failure as the dependent variable are consistent with previous results.

\section{[Insert Table 5 Here]}

\section{Other Robustness Checks}

We fitted multiple additional models to test the robustness of our findings. First, following the financial life cycle approach (Berger \& Udell, 1998), ventures may receive informal angel funding before they raise formal VC. We therefore additionally control for the availability of angel funding in the venture's state as a robustness check. This information is retrieved from Pitchbook data. Findings suggest that even when controlling for the availability of angel funding in the state of origin the paucity of $\mathrm{VC}$ funding in that state remains a significant predictor of relocation to $\mathrm{CA}$ or MA. We also point out that stable differences in the availability of angel money across states (e.g., ARI Halo Report, 2015) are already incorporated in the main models in Table 4 through the state fixed effects.

Second, instead of using a dummy variable as the dependent variable in the relocation analyses, we also used a continuous measure of VC fund availability (both absolute and relative) in the state of destination as alternative dependent variables. A two-step Heckman approach was used, with the likelihood to relocate as a selection regression. Conditional upon relocating, we find 
that ventures founded in states with a lower availability of VC are more likely to relocate to states with a greater availability of VC. Thus, our results remain robust.

Related, we also analyzed relocations to CA, MA or NY instead of CA or MA. NY has experienced a substantial increase in terms of VC fund availability during our sample period and is currently recognized as the third VC center (NVCA, 2015). When including NY as additional relocation state, findings are broadly in line with prior results. More specifically, the level of VC fund availability has a negative effect on the hazard of relocation to CA, MA or NY (although only the effect of the relative level of $\mathrm{VC}$ is significant, $\mathrm{p}<.01)$. Next, ventures relocating to CA, MA or NY are more likely to receive initial VC compared to those that stay in their home state $(\mathrm{p}<.05)$, although there is no significant difference in the probability of receiving initial VC between homegrown and relocated ventures. Hence, while results remain qualitatively similar, they are somewhat weaker, which may be due to the fact that NY had considerably less VC compared to CA and MA during most of the period of our analysis, hence limiting the benefits of relocating to NY as a resource dependence tactic. Overall, these additional tests strengthen our earlier claims that ventures relocate to the $\mathrm{VC}$ richest states as a dependence-reducing action.

Third, we acknowledge the heterogeneity of economic activity and VC fund availability within CA and MA; the Boston and San Francisco Bay areas are the VC richest areas in these states. We therefore added economic area fixed effects instead of state fixed effects when comparing the hazard ratios of attracting initial $\mathrm{VC}$ for ventures located in CA or MA. These fixed effects control for all, even unmeasured (or unobservable) stable differences between areas. Findings again remain robust.

Fourth, we explored whether opening up a branch in CA or MA could be an alternative, less dramatic resource dependence tactic relative to venture relocation. Interestingly, the findings 
show that opening up a branch in CA or MA also increases the likelihood of receiving initial VC with $89 \%$ (p-value <.05) compared to ventures that remain in their home state. The effect is, however, much lower compared to a relocation of activities to CA or MA (as reported in Table 4), which leads to a 3.7 times increase in the likelihood of raising initial VC. Moreover, ventures with a branch in $\mathrm{CA}$ or MA are not different from ventures founded in CA or MA in terms of the likelihood of receiving initial VC. Hence, opening up a branch may also help to raise initial VC, but it is not as effective as relocation.

Finally, we explored whether other important resources drive relocation, next to availability of VC funding, focusing on human capital availability and industry density. These robustness tests show that ventures founded in states with a low proportion of science and engineering graduate students have a higher probability of relocating to states that excel in terms of the number of science and engineering graduates students. Similarly, a low industry density stimulates ventures to relocate to states with a high industry density. Taken together, this suggests that a lack of resources in a venture's founding state is a strong driver of the decision to relocate.

\section{DISCUSSION}

Using an RDT perspective, we investigate venture relocation as an unexplored tactic entrepreneurs may use to reduce their dependence on a limited set of VCs in their home state and increase their probability of raising initial VC. We show that ventures founded in states with lower VC fund availability are more likely to relocate to the $\mathrm{VC}$ richest states (i.e., CA or MA) thereby reducing the constraints induced by their initial geographic location. In addition, ventures that relocated to the $\mathrm{VC}$ richest states are more likely to attract initial VC after relocating. These findings highlight that entrepreneurs relocate to the VC richest states as a resource dependence tactic. However, our 
post-hoc analyses also show that relocated ventures are more likely to fail relative to ventures that stay in their VC poor home state.

Our findings have important implications. For the VC literature, we enrich existing insights on the role of proximity in $\mathrm{VC}$ investment decisions. Whereas earlier studies have stressed the importance of proximity to a large pool of VCs for attracting initial VC, we lacked insights on whether relocated ventures can benefit from the increased availability of VC in their new location. Indeed, given limited local embeddedness, relocated ventures may be at a disadvantage relative to home-grown ventures. However, ventures that relocate to the VC richest states have a greater probability of attracting initial $\mathrm{VC}$ than ventures that remain in $\mathrm{VC}$ poorer states and, surprisingly, than ventures that are founded in the VC richest states. As such, our findings suggest that a lower local embeddedness does not necessarily deter access to VC.

The surprising finding that ventures that relocate to the VC richest states have a greater probability of attracting initial VC than ventures that are founded in these states, may be consistent with signaling theory. Relocation is easily observable and difficult or costly to imitate by low quality ventures, which are characteristics of credible signals (Connelly et al., 2011). Relocation indeed implies a substantial cost, including both direct and indirect costs for the venture as well as social costs for the entrepreneur (Michelacci \& Silva, 2007). Hence, relocation could serve as a signal of unobservable venture quality to VCs because only the "best" entrepreneurs (ventures) are likely to relocate (Stam, 2007). Additional tests confirm our expectations. Specifically, if signaling is the mechanism driving our result one would theoretically expect that signals (i.e., relocations) have stronger effects for ventures characterized by higher uncertainty (e.g., Stuart, Hoang \& Hybels, 1999). Unreported tests show that the effect of relocating to CA or MA on the probability 
of raising initial $\mathrm{VC}$ is strongest for ventures with lower historical sales growth and younger ventures; two types of ventures for which prospects are more uncertain.

With this study, we also move beyond the dominant focus on initial location decisions within the broader entrepreneurship literature. This is important since the majority of these studies implicitly assume location to be perpetual rather than subject to change (Carroll \& Hannan, 1989). Entrepreneurs can, however, decide whether they opt to remain active in the state where their initial resource providers are situated or relocate to more munificent states. As such, we hope that our findings stimulate future researchers to join our interest in venture relocation driven by external resource dependencies.

Our findings further extend existing evidence on the entrepreneurial ecosystem in VC rich states, such as CA or MA. These states are considered very attractive for high-tech ventures, even though ventures founded in these regions tend to have higher failure rates (Buenstorf \& Guenter, 2011; Gilbert, McDougall \& Audretsch, 2008). Our findings show that this paradox holds not only for high-tech ventures founded in these states, but also applies to relocation decisions. Hence, ventures that move to CA or MA are more likely to raise initial VC, but also exhibit higher failure rates compared to those that stay in less $\mathrm{VC}$ rich states.

We also contribute to the resource dependence literature. Findings support our general claim that entrepreneurs do not only apply resource dependence tactics to manage dependencies within the boundaries of their current location, but may also change the location itself as a resource dependence strategy. Moreover, while the basic ideas of the resource dependence perspective have become "accepted and taken for granted", they are "not as rigorously explored and tested as it might be" (Pfeffer \& Salancik, 2003, pp. xxxiii). One such idea is that the tactics used to alleviate resource dependencies are likely to produce new patterns of dependence (Pfeffer, 1987). Indeed, 
Hillman et al. (2009) argue that the interrelation of resource dependence patterns represents one of the most underdeveloped areas within the resource dependence literature. In this respect, our study suggests that the relocation to resource rich locations helps ventures to form relationships with important resource providers, in itself a dependence-reducing tactic. However, at the same time, relocation to resource rich locations comes at a cost. Ventures that relocate to the VC richest states have a higher failure risk compared to those that stay in their home state. Overall, we show that tactics to reduce external dependence may have multiple, conflicting outcomes and will never fully eliminate all resource dependencies (Pfeffer, 1987).

\section{Limitations}

Despite our contributions, our paper also has a number of limitations, which may provide opportunities for future research. First, we specifically focus on the supply of a very particular resource, namely VC. While we do control for other sources of financing, such as bank financing, or the availability of angel finance in our robustness checks, we do not capture all potential financial resource providers for the high-tech ventures we study. However, compared to the above mentioned alternatives, VC is more geographically constrained. VCs also provide larger amounts of finance, creating substantial resource dependencies for ventures with high growth ambitions. In this respect, we also highlight that our observation period ends in 2009, when new sources of entrepreneurial finance, such as crowdfunding, were still in their infancy. An interesting question that arises is the role of crowdfunding for ventures founded in VC poor regions. Recent literature on crowdfunding suggests that crowdfunding is also spatially clustered, but not as much as VC (e.g., Mollick \& Robb, 2016).

Second, we assumed that a relocated venture would not have the same level of embeddedness in its new location as a home-grown venture. Unfortunately, we have no detailed 
insight into what relationships an entrepreneur may have already established in CA or MA prior to relocation (e.g., with customers or suppliers). Such data might help future scholars to provide finer-grained insight as to when the balance tips in favor of relocating.

Third, we made the implicit assumption that ventures that receive initial VC have accessed such funds from a VC within that state. Unfortunately, we do not have the data to validate this assumption. However, since VCs located in CA or MA are known to prefer local investing (Chen et al., 2010), we do believe ours is a reasonable assumption to make; i.e. that ventures attracting funding from VCs in CA or MA do so from VCs that are also located in CA or MA.

Finally, an interesting avenue for further research is to explore international rather than domestic relocations to $\mathrm{CA}$ or MA. In addition to earlier studies that focus on international relocations of VC-backed ventures (e.g., Cumming et al., 2009), examining international relocations of non-VC-backed ventures would enrich the debate on relocation as a resource dependence tactic.

Taken together, an interesting avenue for future research is hence to deepen our understanding of the attractiveness of specific eco-systems to entrepreneurs, for example the extent to which place, context and potential are factors that encourage geographic mobility.

\section{Practical Implications}

Our findings provide valuable insights to entrepreneurs and policymakers. For entrepreneurs, our findings show that changing one's venture location may be an effective strategy to reduce dependencies induced by a VC poor home environment. Entrepreneurs can thus increase their odds of attracting initial VC by relocating their ventures. However, entrepreneurs have to bear in mind that relocation to attract initial VC is a high-risk strategy. Much like warnings about increased competition and congestion effects in VC rich states, our research also points to dangers of 
relocating to such states in the form of higher failure rates. For policymakers, prior research has shown that $\mathrm{VC}$ poor states suffer from lower start-up rates, but we highlight an additional concern; namely, that ventures — once founded — are also more likely to relocate their activities out of these states. This additional downside has been largely overlooked by academic scholars and practitioners.

\section{Conclusion}

In sum, extant research has focused on the actions entrepreneurs take to manage their external resource dependencies within the constraints of their existing geographic location. We provide evidence of an unexplored tactic entrepreneurs can use to reduce their dependence on a limited set of VCs in their home state, namely relocating to the VC richest states. Using data on U.S. hightech ventures, we show that ventures founded in states with a lower VC fund availability are more likely to relocate to CA or MA. Interestingly, ventures that do so are also more likely to attract initial VC compared to those ventures that stay in their home state as well as compared to homegrown ventures. Overall, our evidence shows that entrepreneurs do not necessarily take the constraints imposed by their geographic environment as given and some may relocate to change their "playing field".

\section{REFERENCES}

Aldrich, H.E., Ruef, M. (2006). Organizations evolving (Second ed.). London, UK: Sage.

Allison, P.D. (1995). Survival analysis using the SAS® System: A practical guide. Cary, NC: SAS Institute Inc.

Amezcua, A.S., Grimes, M.G., Bradley, S.W., \& Wiklund, J. (2013). Organizational sponsorship and founding environments: A contingency view on the survival of business-incubated firms, 1994-2007. Academy of Management Journal, 56(6), 1628-1654.

Amit, R., Brander, J., \& Zott, C. (1998). Why do venture capital firms exist? Theory and Canadian evidence. Journal of Business Venturing, 13(6), 441-466.

ARI Halo Report. (2015). The Angel Resource Institute (ARI) at Willamette University 2015 Annual ARI Halo Report, a national survey of angel group investment activity sponsored by PitchBook. Retrieved October 15 from https://angelresourceinstitute.org/reports/halo-reportfull-version-ye-2015.pdf 
Berger, A. N., \& Udell, G. F. (1998). The economics of small business finance: The roles of private equity and debt markets in the financial growth cycle. Journal of Banking \& Finance, 22(6), 613-673.

Best, M.H. (2015). Greater Boston's industrial ecosystem: A manufactory of sectors. Technovation, 39, 4-13.

Bradley, S.W., Aldrich, H., Shepherd, D.A., \& Wiklund, J. (2011). Resources, environmental change and survival: Asymmetric paths of young independent and subsidiary organizations. Strategic Management Journal, 32(5), 486-509.

Brouwer, A.E., Mariotti, I., \& van Ommeren, J.N. (2004). The firm relocation decision: An empirical investigation. Annals of Regional Science, 38(2), 335-347.

Buenstorf, G., \& Guenther, C. (2011). No place like home? Relocation, capabilities, and firm survival in the German machine tool industry after World War II. Industrial and Corporate Change, 20(1), 1-28.

Carpenter, R.E., \& Petersen, B.C. (2002a). Is the growth of small firms constrained by internal finance? Review of Economics and Statistics, 84(2), 298-309.

Carpenter, R.E., \& Petersen, B.C. (2002b). Capital market imperfections, high-tech investment, and new equity financing. Economic Journal, 112(477), F54-F72.

Carroll, G.R., \& Hannan, M.T. (1989). Density delay in the evolution of organizational populations - a model and 5 empirical tests. Administrative Science Quarterly, 34(3), 411-430.

Chen, H., Gompers, P., Kovner, A., \& Lerner, J. (2010). Buy local? The geography of venture capital. Journal of Urban Economics, 67(1), 90-102.

Connelly, B.L., Certo, S.T., Ireland, R.D., \& Reutzel, C.R. (2011). Signaling theory: A review and assessment. Journal of Management, 37(1), 39-67.

Cumming, D., Fleming, G., \& Schwienbacher, A. (2009). Corporate relocation in venture capital finance. Entrepreneurship Theory and Practice, 33(5), 1121-1155.

Cumming, D., \& Dai, N. (2010). Local bias in venture capital investments. Journal of Empirical Finance, 17(3), 362-380.

Cumming, D., \& Li, D. (2013). Public policy, entrepreneurship, and venture capital in the United States. Journal of Corporate Finance, 23, 345-367.

Dahl, M.S., \& Sorenson, O. (2012). Home sweet home: Entrepreneurs' location choices and the performance of their ventures. Management Science, 58(6), 1059-1071.

Deloof, M., \& La Rocca, M. (2015). Local financial development and the trade credit policy of Italian SMEs. Small Business Economics, 44(4), 905-924.

Devigne, D., Vanacker, T., Manigart, S., \& Paeleman, I. (2013). The role of domestic and crossborder venture capital investors in the growth of portfolio companies. Small Business Economics, 40(3), 553-573.

Dunford, R. (1987). The suppression of technology as a strategy for controlling resource dependence. Administrative Science Quarterly, 512-525.

Ebben, J., \& Johnson, A. (2006). Bootstrapping in small firms: An empirical analysis of change over time. Journal of Business Venturing, 21(6), 851-865.

Feldman, M. P. (2014). The character of innovative places: entrepreneurial strategy, economic development, and prosperity. Small Business Economics, 43(1), 9-20. 
Folta, T. B., Cooper, A. C., \& Baik, Y. S. (2006). Geographic cluster size and firm performance. Journal of Business Venturing, 21(2), 217-242.

Foreman-Peck, J., \& Nicholls, T. (2015). Inter-regional mobility of entrepreneurial SMEs. The Annals of Regional Science, 54(1), 57-87.

Fried, V. H., \& Hisrich, R. D. (1994). Toward a model of venture capital investment decision making. Financial management, 28-37.

Fritsch, M., \& Schilder, D. (2008). Does venture capital investment really require spatial proximity? An empirical investigation. Environment and Planning A, 40(9), 2114-2131.

Galbraith, C. S., Rodriguez, C. L., \& DeNoble, A. F. (2008). SME competitive strategy and location behavior: An exploratory study of high-technology manufacturing. Journal of Small Business Management, 46(2), 183-202.

Gilbert, B.A., McDougall, P.P., \& Audretsch, D.B. (2008). Clusters, knowledge spillovers and new venture performance: An empirical examination. Journal of Business Venturing, 23(4), 405-422.

Gompers, P. A. (1995). Optimal investment, monitoring, and the staging of venture capital. The Journal of Finance, 50(5), 1461-1489.

Gompers, P. A., \& Lerner, J. (1998). What drives venture capital fundraising? Brookings Papers on Economic Activity. Microeconomics, 149-192.

Gupta, A. K., \& Sapienza, H. J. (1992). Determinants of venture capital firms' preferences regarding the industry diversity and geographic scope of their investments. Journal of business Venturing, 7(5), 347-362.

Hallen, B.L. (2008). The causes and consequences of the initial network positions of new organizations: From whom do entrepreneurs receive investments? Administrative Science Quarterly, 53(4), 685-718.

Hallen, B.L., \& Eisenhardt, K.M. (2012). Catalyzing strategies and efficient tie formation: How entrepreneurial firms obtain investment ties. Academy of Management Journal, 55(1), 35-70.

Hecker, D.E. (2005). High-technology employment: A NAICS-based update. Monthly Labor Review, 128(7), 57-72.

Heckman, J.J. (1979). Sample selection bias as a specification error. Econometrica, 47(1), 153161.

Hellmann, T. F., Schure, P., \& Vo, D. (2015). Angels and Venture Capitalists: Substitutes or Complements? Saïd Business School WP, 2.

Hillman, A.J., Withers, M.C., \& Collins, B.J. (2009). Resource dependence theory: A review. Journal of Management, 35(6), 1404-1427.

Holmes, R. M., Zahra, S. A., Hoskisson, R. E., DeGhetto, K., \& Sutton, T. (2016). Two-way streets: The role of institutions and technology policy in firms' corporate entrepreneurship and political strategies. The Academy of Management Perspectives, 30(3), 247-272.

Hulsinck, W., Manuel, D., \& Bouwman, H. (2007). Clustering in ICT: from Route 128 to Silicon Valley, from DEC to Google, from hardware to content. ERIM Report Series Research in Management: Rotterdam: Erasmus Research Institute of Management.

Isabella, L.A. (1990). Evolving interpretations as a change unfolds - How managers construe key organizational events. Academy of Management Journal, 33(1), 7-41. 
Isenberg, D., \& Onyemah, V. (2016). Fostering scaleup ecosystems for regional economic growth. Innovations, 11(1-2), 60-79.

Kaufman Foundation (2016). Angels. Retrieved October 20, 2016 from http://www.kauffman.org/microsites/state-of-the-field/topics/finance/equity/angels.

Knoben, J., \& Oerlemans, L. A. G. (2008). Ties that spatially bind? A relational account of the causes of spatial firm mobility. Regional Studies, 42(3), 385-400.

Knoben, J., Oerlemans, L.A.G., \& Rutten, R. (2008). The effects of spatial mobility on the performance of firms. Economic Geography, 84(2), 157-183.

Knoben, J. (2011). The geographic distance of relocation search: An extended resource-based perspective. Economic Geography, 87(4), 371-392.

Kulchina, E. (2016). Personal preferences, entrepreneurs' location choices, and firm performance. Management Science, 62(6), 1814-1829.

Lee, C., Lee, K., \& Pennings, J.M. (2001). Internal capabilities, external networks, and performance: A study on technology-based ventures. Strategic Management Journal, 22(6-7), 615-640.

Levine, D.I., \& Toffel, M.W. (2010). Quality management and job quality: How the ISO 9001 standard for quality management systems affects employees and employers. Management Science, 56(6), 978-996.

Li, K., \& Prabhala, N. R. (2007). Self-selection models in corporate finance. In E. B. Eckbo (Ed.), Handbook of Corporate Finance: Empirical Corporate Finance (pp. 37-86). North-Holland: Elsevier.

Mäkelä, M.M., \& Maula, M.V.J. (2006). Interorganizational commitment in syndicated crossborder venture capital investments. Entrepreneurship Theory and Practice, 30(2), 273-298.

Michelacci, C., \& Silva, O. (2007). Why so many local entrepreneurs? Review of Economics and Statistics, 89(4), 615-633.

Mollick, E., \& Robb, A. (2016). Democratizing Innovation and Capital Access. California management review, 58(2), 72-87.

Neumark, D., Wall, B., \& Zhang, J.F. (2011). Do small businesses create more jobs? New evidence for the United States from the National Establishment Time Series. Review of Economics and Statistics, 93(1), 16-29.

NVCA (2010). National Venture Capital Association Yearbook. Washington, DC: National Venture Capital Association.

NVCA (2015). National Venture Capital Association Yearbook. Washington, DC: National Venture Capital Association.

Paglia, J. K., \& Harjoto, M.A. (2014). The effects of private equity and venture capital on sales and employment growth in small and medium-sized businesses. Journal of Banking and Finance, 47, 177-197.

Pfeffer, J. (1987). A resource dependence perspective on intercorporate relations. In M.S. Mizruchi, \& M. Schwartz (Eds.), Intercorporate relations: The structural analysis of business. Cambridge, UK: Cambridge University Press.

Pfeffer, J., \& Salancik, G. (1978). The External Control of Organizations. New York, NY.: Harper and Row. 
Pfeffer, J., \& Salancik, G. (2003). The External Control of Organizations: A Resource Dependence Perspective. Stanford, CA: Stanford University Press.

Plummer, L. A., Allison, T. H., \& Connelly, B. L. (2016). Better together? Signaling interactions in new venture pursuit of initial external capital. Academy of Management Journal, 59(5), 15851604.

Popov, A. (2014). Venture capital and industry structure: Evidence from local U.S. markets. Review of Finance, 18(3), 1059-1096.

Puri, M., \& Zarutskie, R. (2012). On the life cycle dynamics of venture-capital- and non-venturecapital-financed firms. Journal of Finance, 67(6), 2247-2293.

Sapienza, H.J., Manigart, S., \& Vermeir, W. (1996). Venture capitalist governance and value added in four countries. Journal of Business Venturing, 11(6), 439-469.

Sapienza, H.J., Korsgaard, M.A., \& Forbes, D. (2003). The self-determination motive and entrepreneurs' choice of financing. Cognitive Approaches to Entrepreneurship Research, 6, 107-140.

Shane, S., \& Cable, D. (2002). Network ties, reputation, and the financing of new ventures. Management Science, 48(3), 364-381.

Schutjens, V., \& Stam, E. (2003). The evolution and nature of young firm networks: a longitudinal perspective. Small Business Economics, 21(2), 115-134.

Sorenson, O., \& Stuart, T.E. (2001). Syndication networks and the spatial distribution of venture capital investments. American Journal of Sociology, 106(6), 1546-1588.

Stam, E. (2007). Why butterflies don 't leave: Locational behavior of entrepreneurial firms. Economic Geography, 83(1), 27-50.

Stangler, D., Tareque, I., \& Morelix, A. (2016). Trends in Venture Capital, Angel Investments, and Crowdfunding across the Fifty Largest US Metropolitan Areas. Retrieved January 30, 2017 from https://papers.ssrn.com/sol3/Papers.cfm?abstract_id=2881534.

Stuart, T. E., Hoang, H., \& Hybels, R. C. (1999). Interorganizational endorsements and the performance of entrepreneurial ventures. Administrative Science Quarterly, 44(2), 315-349.

Stuart, T., \& Sorenson, O. (2003). The geography of opportunity: Spatial heterogeneity in founding rates and the performance of biotechnology firms. Research Policy, 32(2), 229-253.

Tsvetkova, A., Thill, J. C., \& Strumsky, D. (2014). Metropolitan innovation, firm size, and business survival in a high-tech industry. Small Business Economics, 43(3), 661-676.

Vanacker, T., Collewaert, V., \& Paeleman, I. (2013). The relationship between slack resources and the performance of entrepreneurial firms: The role of venture capital and angel investors. Journal of Management Studies, 50(6), 1070-1096.

Vanacker, T. R., \& Manigart, S. (2010). Pecking order and debt capacity considerations for highgrowth companies seeking financing. Small Business Economics, 35(1), 53-69.

Welbourne, T. M., Neck, H. M., \& Meyer, G. D. (1999). Human resource slack and venture growth: an exploratory analysis of growing employees at a faster rate than sales. Frontiers of entrepreneurship research, 19, 480-490.

Welter, F. (2007). Entrepreneurship in West and East Germany. International Journal of Entrepreneurship and Small Business, 4(2), 97-109.

Weterings, A., \& Knoben, J. (2013). Footloose: An analysis of the drivers of firm relocations over different distances. Papers in Regional Science, 92(4), 792-811. 
Table 1

Sample Distribution across U.S. States

Distribution of Ventures Founded (Panel A), relocations (Panels B and C) and raised VC finance (Panel D)

\begin{tabular}{|c|c|c|c|c|c|c|c|c|}
\hline \multirow{3}{*}{ State } & \multicolumn{2}{|l|}{$\mathbf{A}$} & \multicolumn{2}{|c|}{$\mathbf{B}$} & \multicolumn{2}{|c|}{$\mathbf{C}$} & \multicolumn{2}{|c|}{$\mathbf{D}$} \\
\hline & \multirow[t]{2}{*}{ Obs } & \multirow[t]{2}{*}{$\%$} & \multirow{2}{*}{\multicolumn{2}{|c|}{$\begin{array}{r}\text { Obs Probability } \\
\text { in \% }\end{array}$}} & \multicolumn{2}{|c|}{ Obs (to Probability } & \multicolumn{2}{|c|}{ Obs Probability } \\
\hline & & & & & CA/MA) & in $\%$ & & $\ln \%$ \\
\hline AK & 287 & .18 & 11 & 3.83 & 0 & .00 & 2 & .70 \\
\hline $\mathrm{AL}$ & 1,599 & 1.03 & 49 & 3.06 & 3 & .19 & 13 & .81 \\
\hline AR & 651 & .42 & 15 & 2.30 & 0 & .00 & 2 & .31 \\
\hline $\mathrm{AZ}$ & 2,963 & 1.91 & 70 & 2.36 & 14 & .47 & 39 & 1.32 \\
\hline $\mathrm{CA}$ & 27,215 & 17.51 & 637 & 2.34 & 37 & .14 & 805 & 2.96 \\
\hline $\mathrm{CO}$ & 3,566 & 2.29 & 115 & 3.22 & 24 & .67 & 70 & 1.96 \\
\hline $\mathrm{CT}$ & 1,797 & 1.16 & 114 & 6.34 & 22 & 1.22 & 38 & 2.11 \\
\hline $\mathrm{DC}$ & 1,004 & .65 & 123 & 12.25 & 3 & .30 & 8 & .80 \\
\hline $\mathrm{DE}$ & 567 & .36 & 50 & 8.82 & 3 & .53 & 2 & .35 \\
\hline FL & 11,043 & 7.10 & 246 & 2.23 & 31 & .28 & 55 & .50 \\
\hline GA & 5,905 & 3.80 & 159 & 3.83 & 15 & .25 & 55 & .93 \\
\hline $\mathrm{HI}$ & 374 & .24 & 8 & 2.14 & 2 & .53 & 1 & .27 \\
\hline IA & 856 & .55 & 22 & 2.57 & 1 & .12 & 5 & .58 \\
\hline ID & 559 & .36 & 27 & 4.83 & 3 & .54 & 6 & 1.07 \\
\hline IL & 5,915 & 3.81 & 150 & 2.54 & 22 & .37 & 83 & 1.40 \\
\hline IN & 2,102 & 1.35 & 51 & 2.43 & 7 & .33 & 30 & 1.43 \\
\hline $\mathrm{KS}$ & 1,151 & .74 & 52 & 4.52 & 1 & .09 & 12 & 1.04 \\
\hline KY & 1,129 & .73 & 39 & 3.45 & 5 & .44 & 12 & 1.06 \\
\hline LA & 1,572 & 1.01 & 32 & 2.04 & 3 & .19 & 11 & .70 \\
\hline MA & 5,010 & 3.22 & 208 & 4.15 & 30 & .60 & 233 & 4.65 \\
\hline MD & 4,038 & 2.60 & 229 & 5.67 & 17 & .42 & 43 & 1.06 \\
\hline ME & 389 & .25 & 8 & 2.06 & 2 & .51 & 4 & 1.03 \\
\hline MI & 4,419 & 2.84 & 106 & 2.40 & 19 & .43 & 40 & .91 \\
\hline $\mathrm{MN}$ & 2,522 & 1.62 & 68 & 2.70 & 10 & .40 & 29 & 1.15 \\
\hline MO & 2,083 & 1.34 & 79 & 3.79 & 11 & .53 & 19 & .91 \\
\hline MS & 654 & .42 & 21 & 3.21 & 0 & .00 & 5 & .76 \\
\hline MT & 350 & .23 & 10 & 2.86 & 2 & .57 & 3 & .86 \\
\hline $\mathrm{NC}$ & 3,742 & 2.41 & 118 & 3.15 & 20 & .53 & 46 & 1.23 \\
\hline ND & 256 & .16 & 6 & 2.34 & 0 & .00 & 1 & .39 \\
\hline $\mathrm{NE}$ & 505 & .32 & 13 & 2.57 & 3 & .59 & 1 & .20 \\
\hline $\mathrm{NH}$ & 797 & .51 & 43 & 5.40 & 25 & 3.14 & 14 & 1.76 \\
\hline $\mathrm{NJ}$ & 5,583 & 3.59 & 285 & 5.10 & 46 & .82 & 56 & 1.00 \\
\hline NM & 696 & .45 & 29 & 4.17 & 3 & .43 & 10 & 1.44 \\
\hline NV & 1,695 & 1.09 & 100 & 5.90 & 47 & 2.77 & 5 & .29 \\
\hline NY & 9,243 & 5.95 & 406 & 4.39 & 72 & .78 & 108 & 1.17 \\
\hline $\mathrm{OH}$ & 4,317 & 2.78 & 120 & 2.78 & 16 & .37 & 44 & 1.02 \\
\hline $\mathrm{OK}$ & 1,231 & .79 & 21 & 1.71 & 0 & .00 & 8 & .65 \\
\hline OR & 1,534 & .99 & 50 & 3.26 & 13 & .85 & 17 & 1.11 \\
\hline PA & 4,790 & 3.08 & 174 & 3.63 & 22 & .46 & 69 & 1.44 \\
\hline PR & 741 & .48 & 1 & .13 & 0 & .00 & 0 & .00 \\
\hline RI & 359 & .23 & 18 & 5.01 & 6 & 1.67 & 1 & .28 \\
\hline $\mathrm{SC}$ & 1,410 & .91 & 37 & 2.62 & 2 & .14 & 9 & .64 \\
\hline SD & 233 & .15 & 10 & 4.29 & 0 & .00 & 3 & 1.29 \\
\hline $\mathrm{TN}$ & 2,195 & 1.41 & 47 & 2.14 & 1 & .05 & 13 & .59 \\
\hline TX & 12,888 & 8.29 & 235 & 1.82 & 29 & .23 & 149 & 1.16 \\
\hline UT & 1,802 & 1.16 & 60 & 3.33 & 21 & 1.17 & 31 & 1.72 \\
\hline VA & 5,585 & 3.59 & 270 & 4.83 & 22 & .39 & 56 & 1.00 \\
\hline VI & 25 & .02 & 0 & .00 & 0 & .00 & 0 & .00 \\
\hline VT & 216 & .14 & 6 & 2.78 & 0 & .00 & 2 & .93 \\
\hline WA & 3,455 & 2.22 & 103 & 2.98 & 30 & .87 & 99 & 2.87 \\
\hline WI & 1,798 & 1.16 & 34 & 1.89 & 3 & .17 & 24 & 1.33 \\
\hline WV & 390 & .25 & 13 & 3.33 & 1 & .26 & 3 & .77 \\
\hline WY & 229 & .15 & 8 & 3.49 & 2 & .87 & 0 & .00 \\
\hline Total & 155,435 & 100.00 & 4,906 & 3.16 & 671 & .43 & 2,394 & 1.54 \\
\hline
\end{tabular}




\section{Table 2}

Sample Description of Venture and State of Origin Characteristics ${ }^{a}$

\begin{tabular}{|c|c|c|c|}
\hline & Average & Median & $\mathbf{N}$ (venture years) \\
\hline \multicolumn{4}{|l|}{ Venture characteristics } \\
\hline Venture size (in $\$)^{1,2}$ & $2,240,749.00$ & $1,128,960.00$ & $1,086,537$ \\
\hline Venture age $^{2}$ & 5.24 & 5.00 & $1,088,190$ \\
\hline Credit report availability (Y/N) & .44 & & $1,088,190$ \\
\hline Venture growth ${ }^{1}$ & .14 & .00 & 932,259 \\
\hline HR slack & .54 & -1.40 & $1,086,521$ \\
\hline \multicolumn{4}{|l|}{ State of origin characteristics } \\
\hline VC funds (absolute) in $\$$ mio. ${ }^{1,2}$ & $1,905.56$ & 233.75 & $1,088,190$ \\
\hline $\begin{array}{l}\mathrm{VC} \text { funds (relative) in } \$ \text { mio per active high-tech } \\
\text { venture }^{1}\end{array}$ & .09 & .02 & $1,088,190$ \\
\hline Industry density ${ }^{2}$ & $3,681.53$ & $1,471.00$ & $1,088,190$ \\
\hline Patents per thousand inhabitants & .30 & .27 & $1,082,979$ \\
\hline GDP per capita (in USD) $)^{1,2}$ & $35,144.26$ & $34,677.00$ & $1,088,190$ \\
\hline Science and engineering graduate students & 11.59 & 11.20 & $1,088,190$ \\
\hline Local banking development ${ }^{2}$ & 32.40 & 17.66 & $1,088,190$ \\
\hline Long term capital tax gains rate & 5.44 & 4.90 & $1,088,190$ \\
\hline Neighbor & .11 & & $1,088,190$ \\
\hline
\end{tabular}

${ }^{a}$ Continuous variables are winsorized on a 5\% level. All independent variables are lagged with one year.

${ }^{1}$ Inflation adjusted measures are included in the analyses.

${ }^{2}$ The $\log$ of this variable is included in the analyses. 


\section{Table 3}

Hazard Ratios and Standard Errors for Predictors of Relocation to CA or MA ${ }^{\mathrm{a}}$

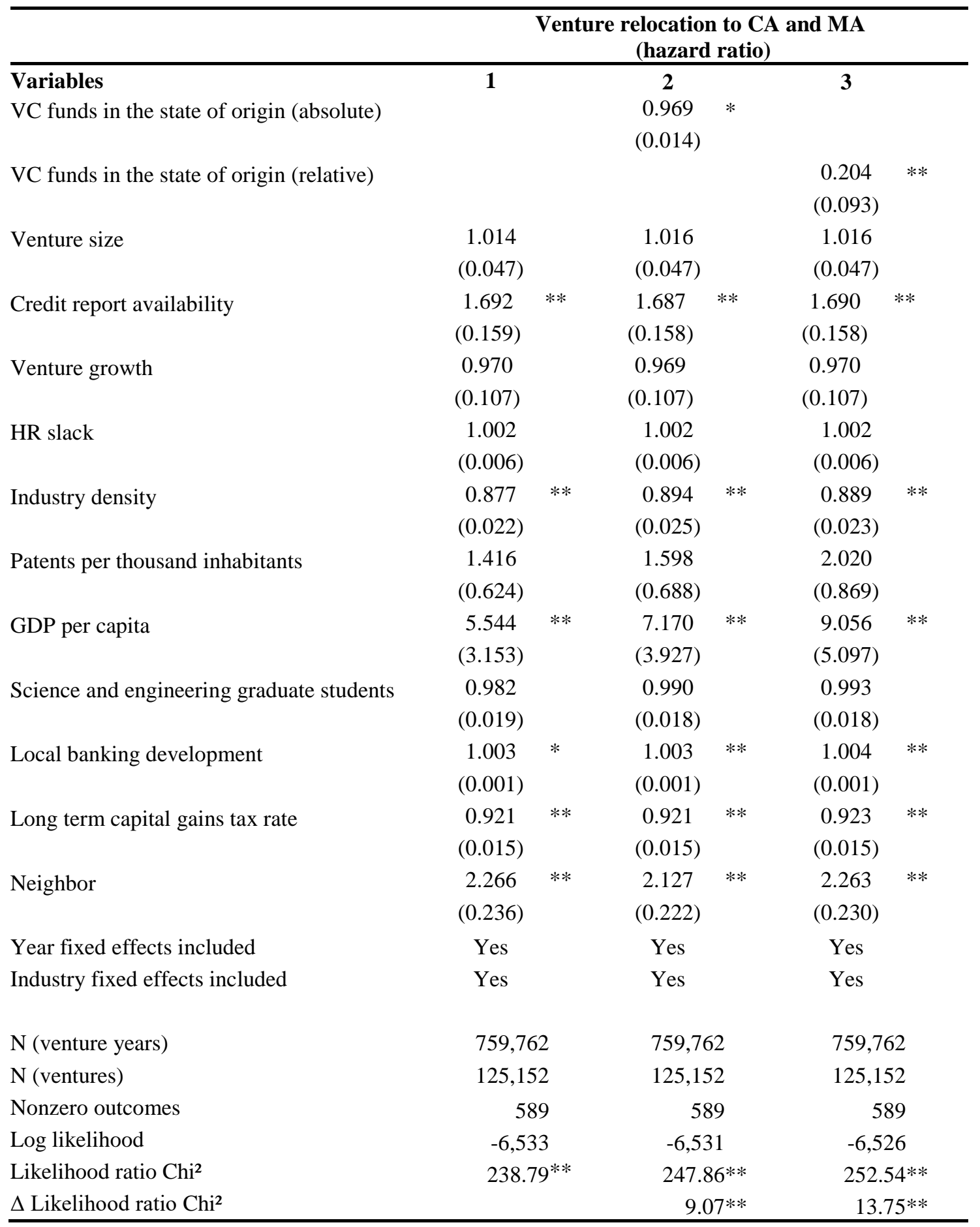

a This table presents the hazard ratios of relocation to CA or MA. The sample used in these regressions solely consists of ventures that did not yet attract VC. Robust standard errors clustered at venture level are reported in parentheses. Significance at 5\% and 1\% level (two-tailed test) is denoted by * and ** respectively. 
Table 4

Hazard Ratios and Standard Errors for Predictors of Initial VC Finance ${ }^{a}$

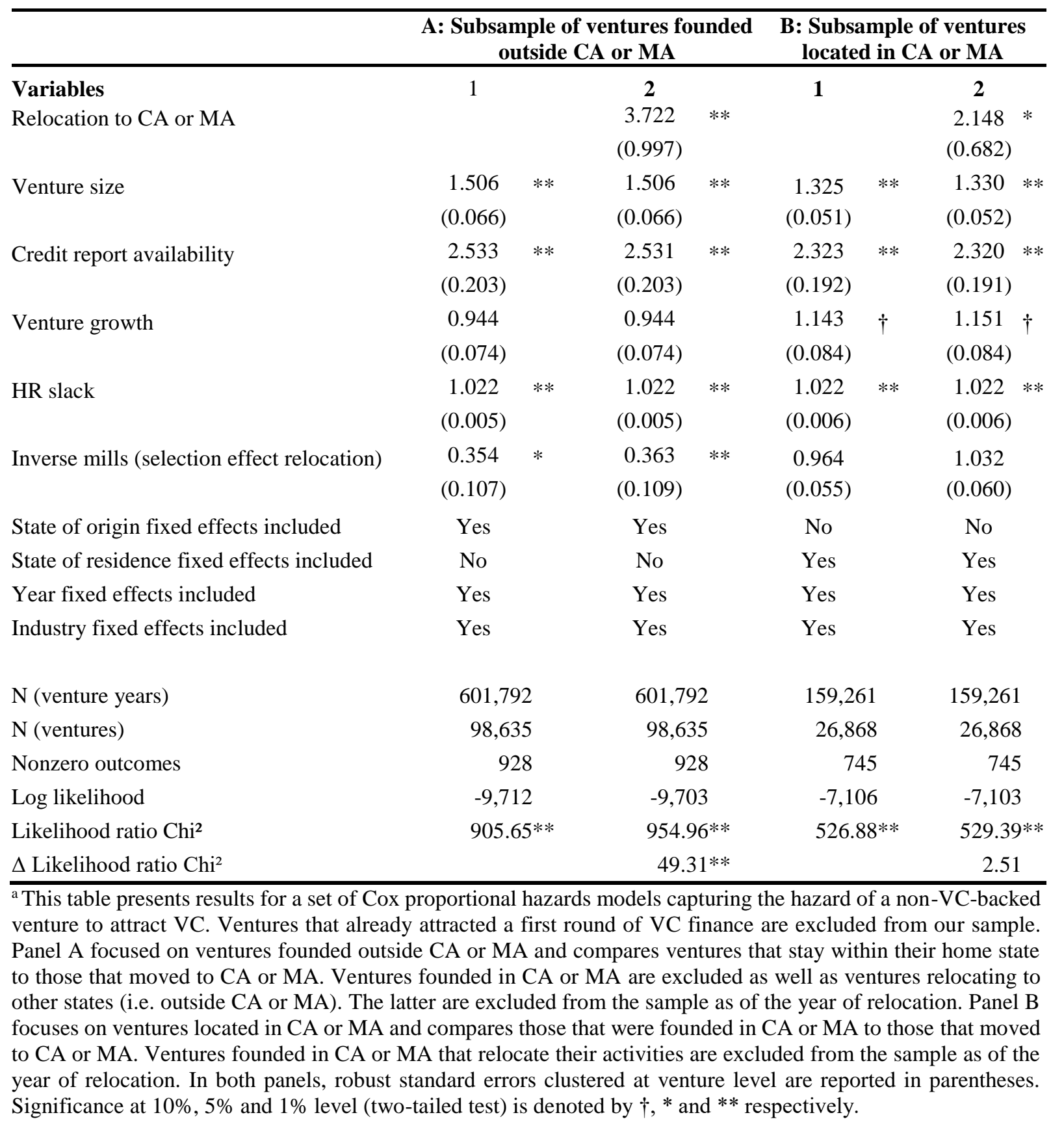




\section{Table 5}

Hazard Ratios and Standard Errors for Predictors of Venture Failure ${ }^{\mathrm{a}}$

\begin{tabular}{|c|c|c|c|c|c|c|c|}
\hline \multirow[b]{2}{*}{ Variables } & \multicolumn{4}{|c|}{$\begin{array}{c}\text { A: Subsample of ventures founded } \\
\text { outside CA or MA }\end{array}$} & \multicolumn{3}{|c|}{$\begin{array}{l}\text { B: Subsample of ventures } \\
\text { located in CA or MA }\end{array}$} \\
\hline & 1 & & 2 & & 1 & & 2 \\
\hline Relocation to CA or MA & & & $\begin{array}{l}1.746 \\
(0.392)\end{array}$ & $*$ & & & $\begin{array}{c}1.452 \\
(0.382)\end{array}$ \\
\hline Venture size & $\begin{array}{c}1.359 \\
(0.034)\end{array}$ & $* *$ & $\begin{array}{c}1.358 \\
(0.034)\end{array}$ & $* *$ & $\begin{array}{c}1.485 \\
(0.042)\end{array}$ & $* *$ & $\begin{array}{l}1.489 \text { ** } \\
(0.042)\end{array}$ \\
\hline Credit report availability & $\begin{array}{c}1.401 \\
(0.059)\end{array}$ & $* *$ & $\begin{array}{c}1.400 \\
(0.059)\end{array}$ & $* *$ & $\begin{array}{c}1.580 \\
(0.102)\end{array}$ & $* *$ & $\begin{array}{c}1.580 \text { ** } \\
(0.102)\end{array}$ \\
\hline Venture growth & $\begin{array}{c}0.792 \\
(0.040)\end{array}$ & $* *$ & $\begin{array}{c}0.791 \\
(0.040)\end{array}$ & $* *$ & $\begin{array}{c}0.969 \\
(0.059)\end{array}$ & & $\begin{array}{c}0.970 \\
(0.059)\end{array}$ \\
\hline HR slack & $\begin{array}{c}1.023 \\
(0.003)\end{array}$ & $* *$ & $\begin{array}{c}1.023 \\
(0.003)\end{array}$ & $* *$ & $\begin{array}{c}1.036 \\
(0.004)\end{array}$ & $* *$ & $\begin{array}{c}1.037 \text { ** } \\
(0.004)\end{array}$ \\
\hline VC financed & $\begin{array}{c}0.255 \\
(0.104)\end{array}$ & $* *$ & $\begin{array}{c}0.254 \\
(0.103)\end{array}$ & $* *$ & $\begin{array}{c}0.642 \\
(0.155)\end{array}$ & $\dagger$ & $\begin{array}{l}0.643 \dagger \\
(0.155)\end{array}$ \\
\hline Inverse mills (selection effect relocation) & $\begin{array}{c}0.418 \\
(0.091)\end{array}$ & $* *$ & $\begin{array}{c}0.419 \\
(0.092)\end{array}$ & $* *$ & $\begin{array}{c}0.979 \\
(0.044)\end{array}$ & & $\begin{array}{c}1.013 \\
(0.050)\end{array}$ \\
\hline State of origin fixed effects included & Yes & & Yes & & No & & No \\
\hline State of residence fixed effects included & No & & No & & Yes & & Yes \\
\hline Year fixed effects included & Yes & & Yes & & Yes & & Yes \\
\hline Industry fixed effects included & Yes & & Yes & & Yes & & Yes \\
\hline $\mathrm{N}$ (venture years) & 609,2 & & 609,2 & & 164,26 & & 164,269 \\
\hline $\mathrm{N}$ (ventures) & 99,5 & & 99,5 & & 27,32 & & 27,324 \\
\hline Nonzero outcomes & 3,0 & & 3,0 & & $1,1 \xi$ & & 1,183 \\
\hline Log likelihood & $-31,4$ & & $-31,4$ & & $-10,4$ & & $-10,458$ \\
\hline Likelihood ratio $\mathrm{Chi}^{2}$ & 4,232 . & $8 * *$ & 4,238 & $30 * *$ & $1,605$. & $3^{* *}$ & $1,605.03 * *$ \\
\hline$\Delta$ Likelihood ratio $\mathrm{Chi}^{2}$ & & & & $2 *$ & & & 0.50 \\
\hline
\end{tabular}

